\title{
Listening to Thitter about Adverse Events OF THE COMIRNATY COVID-19 VACCINE DURING FIRST Weeks of immunisation in Poland
}

\author{
ANDRZEJ JARYNOWSKI \\ Institute for Veterinary Epidemiology and Biostatistics, Freie Universität Berlin, \\ Königsweg 67, 14163 Berlin, Germany \\ e-mail address: a.jarynowski@fu-berlin.de \\ ORCID: 0000-0003-0949-6674
}

KatARZYNA KaCZMAR

Institute of Political Science, Faculty of Social Sciences, University of Wrocław Plac Uniwersytecki 1, 50-137 Wrocław

e-mail address: katarzyna.kaczmar@gmail.com

ORCID: 0000-0001-9976-6716

MARTYNA MADEJ

Institute of Political Science, Faculty of Social Sciences, University of Wrocław Plac Uniwersytecki 1, 50-137 Wrocław

e-mail address: martynam780@gmail.com

ORCID: 0000-0002-6096-3621

\begin{abstract}
Aim. We perform an exploratory study of how Social Media Listening using simple keywords can be useful in pharmacosurveillance of Adverse Events (AE) of COVID-19 vaccines.

Concept. 43375 Tweets about vaccines during the first weeks of Comirnaty COVID-19 vaccine roll-outs in Poland were collected. We analyse the frequency of occurrence of selected common symptoms by infodemiological (related to self-reporting posts) and compare them with the epidemiological (product summary and post-registration) surveillance in Poland.

Results. The AE keywords posting in Social Media is mainly driven by media interest rather than real burden of AE. The best accordance between infodemiological and epidemiological surveillance was found for systemic reactions, however local and gastric reactions seems to be underrepresented in social media.

Conclusion. Infodemiology can be useful in early warning pharmacosurveillance of some AE during massive drug delivery as immunisation. Some keywords of symptoms such as fever or pain seem to be the most promising and due to low cost of monitoring should be incorporated in real-time dashboards for decision makers.
\end{abstract}

Keywords: infodemiology, epidemiological intelligence, vaccine adverse events, COVID-19 


\section{INTRODUCTION}

Efficacy in protecting from severe COVID-19 and adverse events (AEs) were well targeted endpoints of the Pfizer Comirnaty vaccine (EMA, 2020; CDC, 2020). Moreover, our knowledge of COVID-19 vaccines safety has been extended due to post registration passive surveillance (VAERS [North America] or ARR [European Union]) and active surveillance (as V-Safe (Shimabukuro, et al., 2021), Isrealian clinical trials (Barda, et al., 2021)). Immunisation against COVID-19 in Poland began on 27.12.2020 with Comirnaty vaccine with a priority given to healthcare workers and during the first weeks only mRNA vaccines were available (Jarynowski \& Skawina, 2021).

Various Community based / participatory surveillance understood as "the detection and reporting of events of public health significance within a community by community members" (WHO, 2018) were created ad hoc and some people share their adverse events after immunisation in social media. Historically in Poland, social structures with intellectual capacity and ability to cooperate outside the formal system existed (as "Solidarity movement") a few decades ago and are still alive in historical memory (Aaberg \& Sanberg, 2017; Field, 2014). The society uses Internet technology as an independent social media to collaborate and discuss their needs and form the so-called "Twitter Academy of Science" (Jarynowski, 2021) to cope with a radically altered COVID-19 pandemic reality trying to adopt something that suddenly becomes real.

Social Media and social networks are a way to communicate with each other in such new circumstances. On the other hand, Polish society has a high proportion of negative attitudes towards vaccines (Jarynowski \& Skawina, 2021). The widespread use of the Internet and social media provides us with an indispensable source of information on societal dynamics. WHO has developed an analytical artificial intelligence (AI) tool for social media surveillance for some low- and middle-income countries from Africa, South America and Asia (WHO, 2021), however, Slavic languages (such as Polish) are not covered. Poland has not developed extensive real-time monitoring of social and traditional media data on COVID-19 (up to our knowledge) in contrast to richer countries from mainly English-speaking culture, and our project will fill this gap.

Posts mentioning symptoms in Social Media have a long history of use in infection disease since Google Flu trends. However, failure of prediction of actual epidemic size by using known frequencies of influenza-like illness suggest a subjective bias of information needs which have dominated over symptoms during actual disease (Jarynowski \& Wójta-Kempa, 2021).

Vaccination of adults in Poland is a relatively new procedure, as quite a few of even healthcare workers are regularly getting immunised against seasonal Influenza (Jarynowski \& Skawina, 2021). Thus, discussions about vaccination in Social Media seems to be a part of adopting a new reality.

Since the beginning of the vaccination concept of risk-benefit ratio (AE is a part of it) according to evidence-based medicine as well as naive knowledge in the population (lay referral system (Epstein, 1996)) were discussed publicly (IBI, 2021).

Currently, Polish society uses the resources of social networks and virtual media every day, not only to learn facts and information about certain processes 
and events, but also due to the need to confront the views on a given topic. The 21 st century is called the century of information society, in which information and knowledge are the values (Krztoń, 2015). A person who lives under the pressure of constantly raising social prestige is more willing to reach easily usable tools, which can send his/her opinion to the farthest corners of the world with a few clicks of the mouse and keyboard. Due to the fact that the information society consists of various types of ICT, people with their needs and the state and its economy, the COVID-19 pandemic has become the litmus test of its functioning. The methods of communication presented in this article also show how complex the motivations and behaviour of social media users during a crisis situation are.

It's important to mention that discussion on non-severe vaccines AEs was extremely rare in Polish Social Media (Klimuk, et al., 2021) as well not significantly presented in COVID-19 vaccine discourse on Twitter around the world (Lyu, Han, Luli, 2021). Even the fact that vaccination topics gain significant interest during the pandemic (Sycińska-Dziarnowska, Paradowska-Stankiewicz, Woźniak, 2021) on the Internet in general.

Voluntary symptom self-reporting additionally is not too popular in Eastern European societies due to relatively lower tendency (PEW, 2020) to disclose personal information publicly (possibly a post artefact of communism).

Thanks to a relatively simple research technique, which is social media listening, it is possible to analyse what the social discourse on vaccine symptoms looks like in reality. The places where people sort of trade information have changed over the course of the century. Contemporary society, for which information is of high value and ICT technologies are an element of everyday life, there is no need to discuss your views and needs, e.g. in the market or during meetings with neighbours. A relatively anonymised form of activity, which is participation in discussions in social media, is convenient because it does not require a lot of physical effort, is available at any time and may depend only on the mood of a given creator / recipient of Internet content.

\section{MeThods}

This study seeks to evaluate the ability of Social media listening (with Twitter as an example) to monitor real-time discourse on adverse events. Input data of our analysis are:

AE postmarketing registry in Poland of COVID-19 vaccines (mainly Comirnaty) by National Institute of Public Health, which contains 1249 reports submitted between 30.12.2020 - 4.02.2021 (MZ, 2021). Among these we selected 202 descriptions which contain detailed characteristics of the Adverse Event.

To collect tweets related to vaccination, the Twitter API (rtweet package in R) was used. We obtained 43375 Tweets in Polish with given hashtag (inclusion criterium) \#szczepionka (vaccine) between 27.12.2020-27.01.2021.

Product summary from clinical trial, which contains percent of subjects who reported selected symptoms after receiving Comirnaty shots (EMA, 2020). 
For both textual dataset (postmarketing and Social media), we have developed a set of terms, corresponding to each label of our classification (Table 1). The resulting vocabulary was used for counting frequencies of the keywords in the dataset. Prior to counting, we have converted the text to lowercase. We have also stemmed the keywords from the vocabulary. The counts were produced using regular expressions, ensuring search of the single word keyword.

Example of tweet is: "35 godzin po szczepieniu, tylko ból ramienia o stałym nasileniu 2/10 w subiektywnej skali. Pełna wydolność fizyczna i intelektualna/

Table 1.

Selected medical categories and chosen keywords corresponding to given category

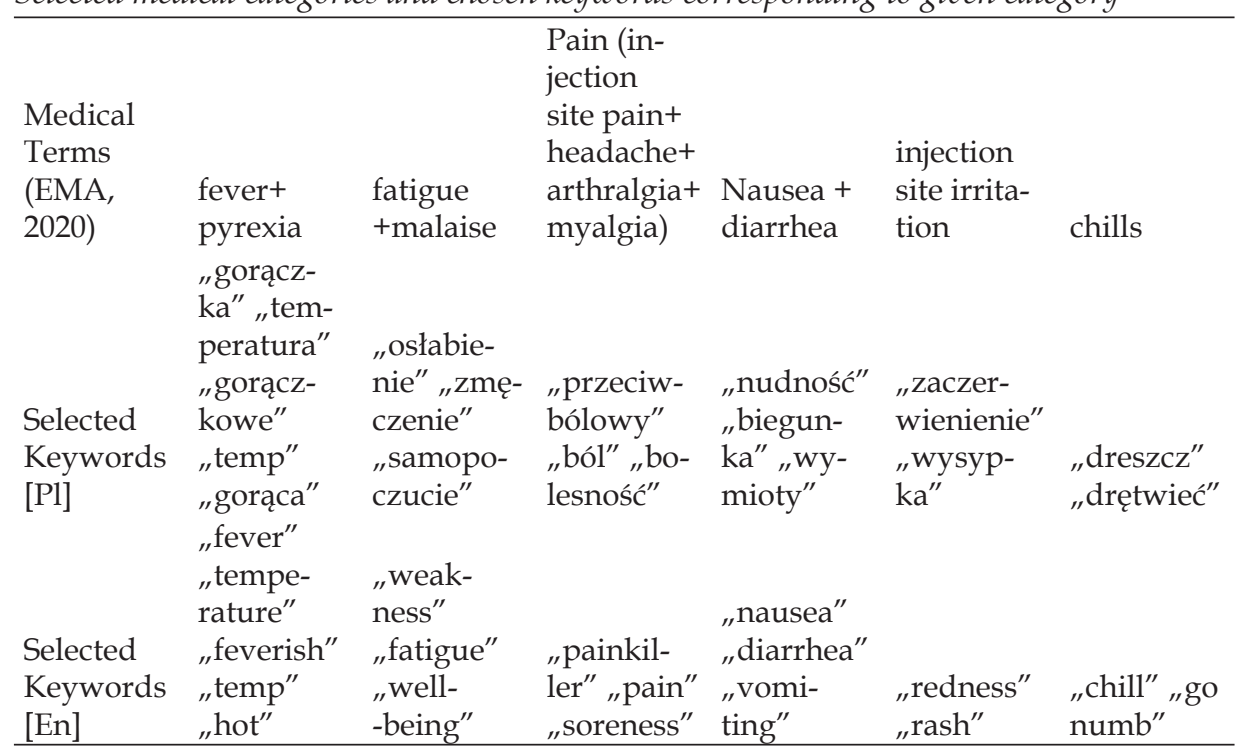

Source: Own research

35 hours post vaccination, only constant arm pain 2/10 on subjective scale. Full physical and intellectual capacity" (@p_grzesiowski 6.01.2021), where pain was counted once.

\section{Results AND Discussion}

Sentinel-like infodemiological methodology was applied to compare how simple counts of keywords on Twitter corresponds to standard epidemiological surveillance. Majority of tweets with AE were detected in the first week of January (when the interest in vaccination was the highest in the society as a new phenomenon (Jarynowski, Skawina, 2021)). On the other hand most of the reports submitted to the Polish State Sanitary Inspection came at the end of January, when the vaccination process sped up (IBI, 2021). 


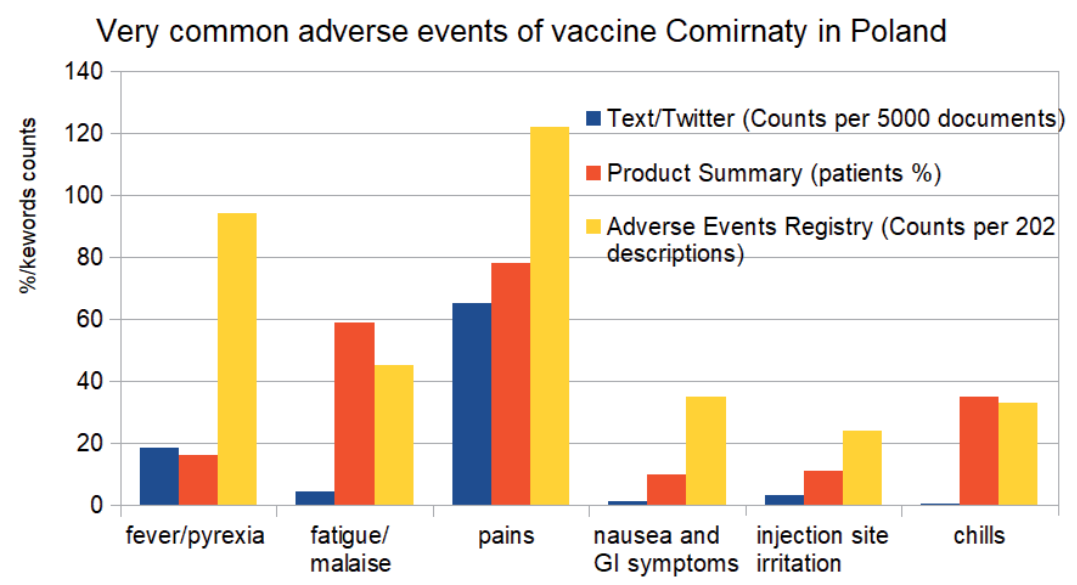

Fig. 1. Comparison of subjective frequencies of given AE categories among infodemiological (Twitter) and epidemiological (post marketing (MZ, 2021) and clinical trial (EMA, 2020) surveillance of Comirnaty Vaccine in Poland in first weeks after introduction.

Source: Own research

AEs frequencies between clinical trials (product characteristics), post marketing registry and keywords surveillance in social media can be compared only with all limitations linked to imperfect symptom's mapping as well credibility and authenticity of reports among others (Fig. 1).

This simple keyword model seems to be quite consistent with post-marketing registry and clinical trials for systemic reactions such as fever and pain. There are some symptoms such as Fatigue, Chills, Nausea (with other GI symptoms) or Injection Site Irritation which seems to be underrepresented by simple keywords searches. Thus, we suggest monitoring pain and fever related posts/queries in social media as a good predictor of AE in the population.

\section{LiMITS}

In contrast to other active surveillance systems after vaccination health checkers as "V-safe" in the US (Shimabukuro et al., 2021), or so-called "guerilla trials" in Russia (Jarynowski et al., 2021) Twitter communication on symptoms is very biased as every civic, self-organised, autonomous activity. Moreover, such a text sample cannot satisfy representativeness due to non-random selection and voluntary basis. Many of the posts were not self-report, but rather discussion about possible AE of the vaccine. Due to low Twitter penetration among elderly and rural areas and on the other hand higher interest of women in their health (Jarynowski, Wójta-Kempa, Belik, 2020), we should expect significant demographic bias. Moreover, in the first weeks of vaccination roll-out mainly health-care workers (widely defined medical committee) were 
vaccinated in Poland (Jarynowski \& Skawina, 2021). Thus, when other professions without medical expertise (e.g. teachers) were vaccinated, the dynamics of AE's discussion were significantly different (Jemielniak \& Krempovych, 2021).

There is a possible problem with pain as the location of pain is difficult to be automatically distinguished. Thus, the semantic meaning of pain class extracted from social media is not directly translated to medical dictionaries used in clinical trials/ post-marketing registries. Moreover, more sophisticated Natural Language Processing tools such as BERT (Jarynowski et al., 2021) or NER (Beliga, et al., 2021) could be applied for better classification.

It should be remembered that Social Media enables publishing to everyone, regardless of their intentions. Statistics from such a type of research may be distorted by the so-called fake news. Therefore, more precisely analysis of at least some of the entries may be necessary in terms of quality.

\section{Conclusions}

It is understood that clinical trials of COVID-19 vaccine are continuing and various post-registration adverse event reporting systems will increase knowledge on safety profile. However, listening to social media in the current pandemic has no equivalent of a similar scale in the modern history of medicine (Jarynowski, 2021). The results from social media cannot be translated one to one into standard epidemiological practice due to different medical biases, but within the concept of perception, yes. For example, we can see underreporting of "gastric" problems by patients, which is a known phenomenon in Eastern Europe (Kowalski, 2011) and may not be related to the actual prevalence of this symptom.

These observations suggest that ad hoc civic communities formed during COVID-19 pandemic should be investigated further and their potential and experience can be potentially considered in planning early warning systems in future. Unfortunately, the trust in biomedical science and medical professionals has declined during COVID-19, especially that it was already low in Eastern Europe (Jarynowski, 2021). Thus, a proper communication program of risk related to vaccination must be developed and adopted into practice.

The analysis of electronic Internet media makes it possible to analyse vaccine perception in Poland and other middle and low income and early detect possible issues as AE. It would be interesting to compare frequencies of AE keywords on other social-containment media as Facebook, YouTube, Instagram or Google Trends (Jarynowski, Wójta-Kempa, Belik, 2020). Moreover, the value of Data Mining on the Internet for revealing the safety profile of vaccines (aiming at increasing transparency regarding their safety and efficacy) was demonstrated - a crucial tool to control the spread of infectious diseases (Jarynowski, et al., 2020).

The research method, which was presented in the article, pinpoints the high exploratory value, which could be brought by social media listening. By looking at actual trends on such a large social media as Twitter, it is possible to find answers to a question about what, currently, is important for certain societies. 
The activity of users of Polish Twitter related to the vaccination against COVID19 presents a social importance of the crisis and the need for dealing with the bothering issues in the most accessible way today, it is via the Internet. Thus, participatory epidemiology/community-based surveillance in Social Media formed during COVID-19 pandemic should be investigated further and its potential and experience can be considered in planning active surveillance in future.

\section{ACKNOWLEDGEMENTS}

The authors acknowledge the E-methodology community. We thank Vitaly Belik and Monika Wójta-Kempa for consultation. Andrzej Jarynowski was partly supported by a German Research Foundation (DFG) grant (458528774).

\section{REFERENCES}

[1] Åberg M, Sandberg M. (2017). Social capital and democratisation: roots of trust in postCommunist Poland and Ukraine. Routledge.

[2] Barda, N., Dagan, N., Ben-Shlomo, Y., Kepten, E., Waxman, J., Ohana, R., ... \& Balicer, R. (2021). Safety of the BNT162b2 mRNA Covid-19 vaccine in a nationwide setting. New England Journal of Medicine, 385(12), 1078-1090. https://doi.org/10.1056/ NEJMoa2110475

[3] Beliga S, Martinčić-Ipšić S, Matešić M, Petrijevčanin Vuksanović I, Meštrović A (2021) Infoveillance of the Croatian Online Media during the COVID-19 Pandemic: a OneYear Longitudinal NLP Study JMIR Infodemiology. 17/09/2021:31540 (forthcoming/in press). https://doi.org/10.2196/31540

[4] CDC. (2020). Local Reactions, Systemic Reactions, Adverse Events, and Serious AdverseEvents: Pfizer-BioNTech COVID-19 Vaccine. Retrieved September 21, 2021, from https://www.cdc.gov/vaccines/covid-19/info-byproduct/pfizer/reactogenicity.html.

[5] EMA. (2020) COVID-19 mRNA Vaccine Comirnaty - summary of product characteristics. Retrieved September 21, 2021, from https://www.ema.europa.eu/en/documents/ product-information/comirnaty-epar-product-information_en.pdf.

[6] Epstein S. (1996). Impure science: AIDS, activism, and the politics of knowledge. Univ of California Press.

[7] Field MG. (2004). HIV and AIDS in the Former Soviet Bloc. New England Journal of Medicine, 351(2):117-120.

[8] Jarynowski, A., Wójta-Kempa, M., \& Belik, V. (2020). Trends in interest of COVID-19 on Polish Internet. Epidemiol Rev, 74, 258-275. https://doi.org/10.32394/pe.74.20

[9] Jarynowski, A., Wójta-Kempa, M., Płatek, D., \& Czopek, K. (2020). Attempt to understand public health relevant social dimensions of COVID-19 outbreak in Poland. Society Register, 4(3), 7-44. https:/ / doi.org/10.14746/sr.2020.4.3.01

[10] Jarynowski, A., \& Wójta-Kempa, M. (2021). Exploring the link between risk perception in internet media and the prevalence of COVID-19 in Europe. International Journal of Infectious Diseases, 103, 450-451. https:/ / doi.org/10.1016/j.ijid.2020.12.001

[11] Jarynowski, A., \& Skawina, I. (2021). Attempt at profiling and regionalisation of COVID-19 vaccine campaigns in Poland-preliminary results. Eur J Transl Clin Med, 4(1), 13-21. https:/ / doi.org/10.31373/ ejtcm/134674 
[12] Jarynowski A, Semenov A, Kamiński M, Belik V. (2021). Mild Adverse Events of Sputnik V Vaccine Extracted from Russian Language Telegram Posts via BERT Deep Learning Model, J Med Internet Res. 18/05/2021:30529 (forthcoming/in press). https://doi. org/10.2196/30529

[13] Jarynowski A, (2021). Phenomenon of participatory "guerilla" epidemiology in postcommunist European countries. Baltic Rim Economies 3, Retrieved September 21, 2021, from https://sites.utu.fi/bre/phenomenon-of-participatory-guerilla-epidemiologyin-post-communist-european-countries/.

[14] Jemielniak, D., \& Krempovych, Y. (2021). An analysis of AstraZeneca COVID-19 vaccine misinformation and fear mongering on Twitter. Public Health. 200, 4-6, https:// doi.org/10.1016/j.puhe.2021.08.019

[15] IBI. (2021). Analiza korzyści i ryzyka szczepień w Polsce [Risk-Benefit analysis of vaccination in Poland]. Retrieved September 21, 2021 from http://interdisciplinary-research. eu/analiza-korzysci-i-ryzyka-szczepien-w-polsce.

[16] Klimiuk K, Czoska A, Biernacka K, Balwicki L. (2021) Vaccine misinformation on social media-topic based content and sentiment analysis of Polish vaccine-deniers' comments on Facebook. Human Vaccines \& Immunotherapeutics. 1-10. https:// doi.org/10.1 080/21645515.2020.1850072

[17] Kowalski P. (2011). About the inevitable: excrement and defecation (in Polish). O tym, co nieuniknione: ekskrementy i defekacja. Colloquia Anthropologica et Communicativa; 4:19-41. Retrieved September 21, 2021, from https://wuwr.pl/cac/article/ view/809/782.

[18] Krztoń, W. (2015). XXI wiek-wiekiem społeczeństwa informacyjnego. Publishing House of Rzeszow University of Technology, 101.

[19] Lyu JC, Han EL, Luli GK (2021) COVID-19 Vaccine-Related Discussion on Twitter: Topic Modeling and Sentiment Analysis. J Med Internet Res; 23(6):e24435. https:/ / doi. org/10.2196/24435

[20] MZ. (2021). NOP - niepożądany odczyn poszczepienny. Czym jest $i$ jak często wystęuje? [NOP - adverse vaccine reaction. What is it and how common is it?]. Retrieved September 21, 2021, from https://www.gov.pl/web/szczepimysie/ niepozadane-odczyny-poszczepienne

[21] PEW. (2020). Public Views About Science in Former communistic countries. Retrieved September 21, 2021, from https://www.pewresearch.org/science/2020/09/29/ science-and-scientists-held-in-high-esteem-across-global-publics/

[22] Shimabukuro, T. T., Kim, S. Y., Myers, T. R., Moro, P. L., Oduyebo, T., Panagiotakopoulos, , ... \& Meaney-Delman, D. M. (2021). Preliminary findings of mRNA Covid-19 vaccine safety in pregnant persons. New England Journal of Medicine, 384(24), 2273-2282. https://doi.org/10.1056/nejmoa2104983

[23] Sycińska-Dziarnowska, M., Paradowska-Stankiewicz, I., \& Woźniak, K. (2021). The Global Interest in Vaccines and Its Prediction and Perspectives in the Era of COVID19. Real-Time Surveillance Using Google Trends. International Journal of Environmental Research and Public Health, 18(15), 7841. https:/ / doi.org/10.3390/ijerph18157841

[24] WHO. (2018) Technical Contributors To The June Who Meeting. A definition for community-based surveillance and a way forward: results of the WHO global technical meeting, France, 26 to 28 June 2018. Euro Surveill. 2019;24(2):1800681. https://doi. org/10.2807/1560-7917.ES.2019.24.2.1800681

[25] WHO. (2021). Early AI-supported Response with Social Listening, Retrieved September 21, 2021, from https:/ / whoinfodemic.citibeats.com. 